\title{
Evolution of FMD Virus Serotype O in Ismailia, Egypt
}

\section{Elshahidy M.S.**, Mona R.Fares *, Shaheen M.A.*, Mandour M. F.** \\ Virology Department, Faculty of Veterinary Medicine, Suez Canal University, Ismailia, Egypt** \\ Department of FMD, Animal Health Research Institute (AHRI), Dokki, Giza, Egypt*}

\begin{abstract}
:
Foot-and-Mouth Disease is a vesicular disease of cloven-hoofed animals. This study was designed for Isolation and identification of FMDV type $\mathrm{O}$ from Ismailia governorate, The collected samples were 41 vesicular fluid and 41 tongue epithelial samples in the period between October 2013 to December 2014. Forty one pooled samples were inoculated in BHK-21 cell culture for isolation. 34 isolates out of 41 pooled samples showed maximum FMDV like $\mathrm{CPE}$. Isolated FMDV were passed for 3 successive passage in BHK21 cells. Last passage of each isolates were identified and confirmed 30 samples possitive as FMDV type $\mathrm{O}$ by complement fixation test and PCR. All FMDV isolates give a suspected bands at 600bp when PCR product examined by agarose gel electrophoresis and UV illumination system. PCR products of three isolates were selected for nucleotide sequencing representing 2 buffaloes from El-Kassasin, Ein Ghosin and one cattle from Abou Sultan. Sequence of VP1 gene of the three isolates were submitted to the gene bank with accession number of (KT121465), (KT121466) and (KT121467). When the VP1 sequence of the current strains compared to other Egyptian and non Egyptian strains submitted to gene bank, it showed that great divergence ranged between 1.2 and $12.7 \%$, meanwhile, sequence comparison with O Sudan 52008 strain showed a great identity ranged between 93 to $94.2 \%$ indicating that the FMDV type O viruses circulating in Ismailia may evolved from the FMDV circulating in Sudan (O Sudan 5 2008).
\end{abstract}

\section{Introduction:}

FMD is highly contagious disease of cloven-footed animals, characterized by presence of vesicles in feet, mouth and mammary glands. FMDV is the causative agent of FMD disease. Clinical signs may be mild or sever according to case and mortalities occur in young animals $(\boldsymbol{O I E}, 2004$ and 2008). FMD caused by virus belong to family Picornaviridae, genus Aphthovirus (Rueckert, 1995). FMDV RNA genome is translated as a single long open reading frame (ORF) into 
nonstructural proteins (NSP) Leader, $\mathrm{Lab}$ and $\mathrm{Lb}$; structural proteins (SP) P1 divided to (1A, 1B, $1 \mathrm{C}$ and 1D) which give VP4, VP2, VP3 and VP1 respectively; NSP P2 divided to (2A, $2 \mathrm{~B}$ and $2 \mathrm{C}$ ); and NSP P3 divided to (3A, 3B or VPg, 3C and 3D) (Lewis et al, 1991; Knipe et al, 1997; Domingo et al, 2002).

FMDV has a high mutation rate because the viral RNA polymerase lacks proofreading activity, resulting in 7 serotypes $(\mathrm{O}, \mathrm{A}, \mathrm{C}$, SAT 1, SAT 2, SAT 3] and Asia1) and include variants (about 80 subtypes) showing a spectrum of antigenic diversity. The SAT1, SAT2 and SAT3 are located in Africa; Asia 1 is located in Asia; O, $\mathrm{A}$, and $\mathrm{C}$ are present in Africa and Asia, South America and occasionally Europe (Knowles and Samuel, 2003).

There are many serotypes of FMD virus as $\mathrm{O}, \mathrm{A}$ and SAT2 were identified In Egypt . Out breaks occur in 1953,1958 and 1960 caused by Type A and SAT2. Type $\mathrm{O}$ was the most prevalent since 1960 and onwards (Zahran, 1960 and Farag et al, 2005). Type A virus caused recent outbreaks in Egypt since 2006 (Knowles et al, 2007). FMD virus SAT2 outbreak was emerged in most Egyptian governorates since 2012 (FAO, 2012). Diagnosis of FMD based on clinical signs, serological confirmatory tests as ELISA and CFT (Giridharan et al, 2005). Due to high sensitivity and speed of RT-
PCR assays it used as confirmatory test to the classical serological and viral isolation methods (Saiz et al, 2003).

Investigation the molecular epidemiology of the disease worldwide Phylogenetic analysis of the virus protein (VP1) region of FMD viruses is required. According to geographic origin of FMDV it can be classified to (Topotype) e.g. the serotype $\mathrm{O}$ can be divided into eleven topotypes have been named Euro-South America, Middle EastSouth Asia , South East Asia, Cathay, West Africa, East Africa 1, East Africa 2, East Africa 3,East Africa 4, Indonesia-1 and Indonesia2 (Samuel and Knowles, 2001; Knowles et al, 2004).

In this study FMDV serotype $\mathrm{O}$ were identified in vesicular fluids and tongue epithelium of infected animals with ELISA and PCR based method and the predicted DNA bands were sequenced to investigate the evolution of FMDV serotype $\mathrm{O}$ circulate in Ismailia area during the period from 2013 to 2014.

\section{Material and Methods}

1. Foot and Mouth Disease virus (FMDV)

FMDV/O/Aga 1993 was locally isolated from Egyptian cattle and buffaloes (El-Nakashly et al, 1996), and provided from FMD department ,VSVRI, Abbassia, Cairo, Egypt .

2. Samples (Epithelial tissue and vesicular fluid samples):

A total of 41 tongue epithelium and 41 vesicular fluid (un ruptured 
vesicles) samples were collected from cattle and buffaloes showed FMD like lesions in five districts of Ismailia governorate (Abu Sultan, Kilo 2, Ein- Ghosin, El-Kassasin and private farm in Ismailia) as shown in Table1.

\section{Cell culture:}

Baby Hamster Kidney cells (BHK 21), were obtained and propagated in virology department, Animal Health Research Institute (AHRI), El-Dokki, Giza, Egypt. The cell culture was used to isolate FMDV from samples according to the technique described by (Macpherson and Stocher, 1962).

4. Enzyme Linked ImmunoSorbent Assay (ELISA):

ELISA test kits (Pirbright) were purchased from IZSLER Biotech Laboratories, Brescia, Italy cat. No. (R 5108) and used for detection and typing of FMDV in tongue epithelium, vesicular fluids and cell culture .

5. Polymerase Chain Reaction (PCR): Viral RNA was extracted from tongue epithelium, vesicular fluid and BHK-21 infected cells using the QIAmp RNA extraction kit (QiagenInc) according to the manufacturer's instruction. One step reverse transcription- polymerase chain reaction (RTPCR) was done using specific foreward and reverse primer according to (Shin et al, 2003). Sequence of primers are forward (5'GACGGYGAYGCTCTGGTCG T3') and reverse (5'GACATGTCCTCCTGCATCTG GTTGAT3') that specific for VP1 gene of serotype $\mathrm{O}$. Thermocycler program parameters were: (1) 30 min at $50^{\circ} \mathrm{C}$, (2) $15 \mathrm{~min}$ at $95^{\circ} \mathrm{C}$, (3) $55 \mathrm{sec}$ at $95^{\circ} \mathrm{C}$, (4) $50 \mathrm{sec}$ at $50^{\circ} \mathrm{C}$, (5) $2.5 \mathrm{~min}$ at $72^{\circ} \mathrm{C}$; repeating steps (3),(4) and (5) for 40 cycles and finally (6) $10 \mathrm{~min}$ at $72^{\circ} \mathrm{C}$.The product was detected by $1.7-2 \%$ agarose in $1 \mathrm{X}$ TBE buffer and Electrophoresis at $100 \mathrm{~V}$ for $60 \mathrm{~min}$ then the band examined by UV transilluminator.

6. Sequence analysis of VP1 coding region of $F M D V$ serotype $O$ :

Viral sequences for comparative analysis were obtained from the National Center for Biotechnology Information http://www.ncbi.nlm.nih.gov).

Sequence alignment and comparisons at the nucleotide and the amino acid level were performed by MEGA 6.06 (6140226), Bioedit 7.2.5. and DNA Baser 
Table (1): Number of suspected field samples from different area of Ismailia governorate

\begin{tabular}{|c|c|c|c|}
\hline District & Cattle & Buffaloes & Total \\
\hline Ismailia & 5 & 5 & 10 \\
\hline Abu-Sultan & 3 & 2 & 5 \\
\hline Kilo-2 & 4 & 3 & 7 \\
\hline Ein-Ghosin & 5 & 4 & 9 \\
\hline El-Kassasin & 4 & 6 & 10 \\
\hline Total & $\mathbf{2 1}$ & $\mathbf{2 0}$ & $\mathbf{4 1}$ \\
\hline
\end{tabular}

\section{Results:}

3.1. Isolation of FMDV serotype $O$ from tongue epithelium and vesicular fluid in BHK-21 cell culture:

Thirty four isolates out of 41 pooled samples showed FMDV like CPE. Supernatant of the last passage of 34 isolates were identified with PCR, ELISA and complement fixation test. Thirty isolates out of 34 proved to be FMDV serotype $\mathrm{O}$.

3.2. Detection of FMDV in tongue epithelium and vesicular fluid using ELISA before and after isolation in Ismailia governorate: Results obtained in Table (2) showed that ELISA assay is more sensitive for detection of FMDV in BHK-21 supernatant $(73.2 \%)$ than direct detection in tounge epithelium and vesicular fluids (70\%).

3. Detection of FMDV in tongue epithelium, vesicular fluid and BHK-21 supernatants using PCR Results obtained in Table (3) showed that PCR assay are more sensitive for detection of FMDV in BHK-21 supernatants with a percentage of $73.2 \%$ ) than direct detection in tongue epithelium and vesicular fluids (43.9\%).

All FMDV isolates give a suspected bands at $600 \mathrm{bp}$ when PCR product examined by agarose gel electrophoresis and UV illumination system as shown in Figure(1).

4. Nucleotide sequences of VP1 gene of FMDV serotype $O$ strains Selected and predicted bands (600bp) of VP1 gene of 3 FMDV isolates were cut and purified for sequencing representing ELKassasin, Ein-Ghosin and AbuSultan strains. Sequences of VP1 gene of the isolated FMDV were submitted to the gene bank with accession number of FMD- EgyptO-1- 2014 (KT121465), FMDEgypt-O-2-2014 (KT121466)and FMD-Egypt-O-3-2014

\section{(KT121467).}

Alignment and comparison of VP1 nucleotides of the three FMDV isolates serotype $\mathrm{O}$ (El-kassasin, Ein-Ghosen and Abu-Sultan strains) illustrated in Table (4) showed that the three sequences are closely related to each other with high identity percent ranged from 98.8 $100 \%$. Ein-Ghosin virus strain are completely identical $\quad(100 \%$ 
identity) to Abu-Sultan strain and quietly distinct from El-Kassasin virus strain with sequence divergence of $1.2 \%$.

A comparison of the deduced amino acid sequences in the VP1 region revealed that most of this study isolates shared high homology with each other. However, the sequences of Abu-Sultan and Ein-Ghosin strains shared the same amino acid sequences and differ in some residues from El-Kassasin strain. Comparison of deduced amino acid sequences of El-Kassasin ,EinGhosin and Abu-Sultan strains with other Egyptian and non Egyptian strains. showed that The common amino acid changes were observed at position 5 (G replaced with $\mathrm{R}$ ), 24 (V-I), 37 (D-N), 58 (P-S), 97 (TA), 108 (H-R), 135 (K-R), 158 (T$\mathrm{K})$ and 170 (L-P).

A comparison of deduced amino acids of El-Kassasin strain with Abu- Sultan and Ein-Ghosin strains, it was found two amino acid substitutions at the position of 17 and 22 in which $\mathrm{N}$ (aspargine) replaced with $\mathrm{K}$ (lysine ) and $\mathrm{T}$ (therionine ) replaced by $\mathrm{P}$ ( proline) respectively.

Phylogenetic analysis of VP1 gene of FMDV serotype $O$
When the VP1 sequence of the current strains compared to other Egyptian and non Egyptian strains submitted to gene bank, it showed divergence ranged between 1.2 and $12.7 \%$, meanwhile, sequence comparison with O Sudan 52008 strain showed a great identity ranged between 93 to $94.2 \%$ indicating that the FMDV serotype $O$ viruses circulating in Ismailia may evolved from the FMDV circulating in Sudan (O Sudan 5 2008) based on the criterion of at least $7.5 \%$ nucleotide difference in the VP1 coding region for a separate lineage and $15 \%$ for a genotype.

Phylogenetic tree of VP1 sequence of 3 FMDV serotype $O$ strains isolated from Ismailia province (ElKassasin, Ein-Ghosin and AbuSultan strains) with other strains showed that the current strains grouped in 2 groups the first group contain EL-Kassasin strain and the other group contain the closely related Ein-Ghosin and Abu-Sultan strains. The three viruses of Ismailia were clustered in the same lineage with (O Sudan 5 2008) of topotype EA-3 that differ from the ME-SA 
Table (2): Sensitivity of ELISA for diagnosis of FMDV serotype $O$ in tounge epithelium, vesicular fluids and BHK-21 supernatants

\begin{tabular}{|c|c|c|c|c|c|c|c|}
\hline \multirow{2}{*}{\multicolumn{2}{|c|}{ District / species }} & \multicolumn{3}{c|}{$\begin{array}{c}\text { ELISA on clinical } \\
\text { samples }\end{array}$} & \multicolumn{3}{c|}{$\begin{array}{c}\text { ELISA in BHK-21 } \\
\text { supernatent }\end{array}$} \\
\cline { 3 - 8 } & & Total & + ve & $\%$ & Total & + ve & $\%$ \\
\hline \multirow{2}{*}{ Ismailia } & Cattle & 5 & 3 & 60 & 5 & 4 & 80 \\
\cline { 2 - 8 } & Buffaloes & 5 & 2 & 40 & 5 & 2 & 40 \\
\hline \multirow{2}{*}{ Abu-Sultan } & Cattle & 3 & 2 & 66.7 & 3 & 2 & 66.7 \\
\cline { 2 - 8 } & Buffaloes & 2 & 1 & 50 & 2 & 1 & 50 \\
\hline \multirow{2}{*}{ Kilo 2 } & Cattle & 4 & 3 & 75 & 4 & 3 & 75 \\
\cline { 2 - 8 } & Buffaloes & 3 & 2 & 66.7 & 3 & 3 & 100 \\
\hline \multirow{3}{*}{ Ein- Ghosin Kassasin } & Cattle & 5 & 4 & 80 & 5 & 4 & 80 \\
\cline { 2 - 8 } & Buffaloes & 4 & 3 & 75 & 4 & 3 & 75 \\
\cline { 2 - 8 } & Cattle & 4 & 2 & 50 & 4 & 4 & 100 \\
\hline \multirow{2}{*}{ Total } & Buffaloes & 6 & 3 & 50 & 6 & 4 & 66.7 \\
\hline
\end{tabular}

*Total \% calculated from the total number of examined samples

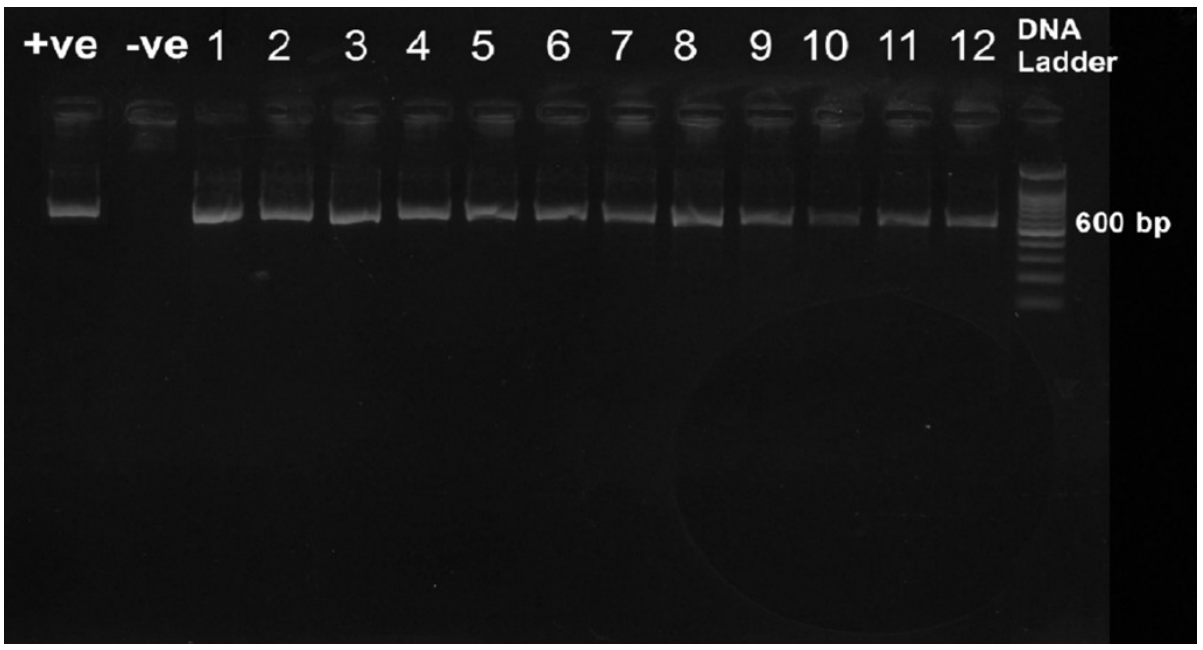

Figure (1): Electrophoretic pattern of VP1 of FMDV serotype $O$ A-In clinical samples 
Table (3): Sensitivity of PCR for diagnosis of FMDV serotype $O$ before and after isolation

\begin{tabular}{|c|c|c|c|c|c|c|c|}
\hline \multirow{2}{*}{ District / species } & \multicolumn{3}{|c|}{$\begin{array}{c}\text { PCR in clinical } \\
\text { samples }\end{array}$} & \multicolumn{3}{c|}{$\begin{array}{c}\text { PCR on BHK-21 } \\
\text { supernatants }\end{array}$} \\
\cline { 3 - 8 } \multicolumn{2}{|c|}{} & Total & + ve & $\%$ & Total & + ve & $\%$ \\
\hline \multirow{2}{*}{ Ismailia } & Cattle & 5 & 2 & 40 & 5 & 4 & 80 \\
\cline { 2 - 8 } & Buffaloes & 5 & 2 & 40 & 5 & 2 & 40 \\
\hline \multirow{2}{*}{ Abu-Sultan } & Cattle & 3 & 1 & 33.3 & 3 & 2 & 66.7 \\
\cline { 2 - 8 } & Buffaloes & 2 & 1 & 50 & 2 & 1 & 50 \\
\hline \multirow{2}{*}{ Kilo 2 } & Cattle & 4 & 2 & 50 & 4 & 3 & 75 \\
\cline { 2 - 8 } & Buffaloes & 3 & 1 & 33.3 & 3 & 3 & 100 \\
\hline \multirow{2}{*}{ El- Kassasin- Ghosin } & Cattle & 5 & 2 & 40 & 5 & 4 & 80 \\
\cline { 2 - 8 } & Buffaloes & 4 & 1 & 25 & 4 & 3 & 75 \\
\cline { 2 - 8 } & Cattle & 4 & 2 & 50 & 4 & 4 & 100 \\
\hline Buffaloes & 6 & 4 & 66.7 & 6 & 4 & 66.7 \\
\hline
\end{tabular}

*Total \% calculated from the total number of examined samples

Table (4): Identity and divergence percent of VP1 sequence of FMDV serotype O isolated from El-Kassasin, Ein-Ghosin and Abu-Sultan

\begin{tabular}{|c|c|c|c|c|c|c|c|c|c|c|c|c|c|c|c|c|}
\hline \multicolumn{17}{|c|}{ Percent Identity } \\
\hline & 1 & 2 & 3 & 4 & 5 & 6 & 7 & 8 & 9 & 10 & 11 & 12 & 13 & 14 & 15 & \\
\hline 1 & & 97.1 & 95.9 & 93.0 & 94.2 & 94.2 & 95.9 & 95.3 & 95.3 & 95.9 & 95.9 & 95.3 & 94.2 & 93.0 & 93.0 & 1 \\
\hline 2 & 3.0 & & 96.5 & 93.6 & 93.6 & 94.7 & 95.3 & 94.7 & 95.9 & 96.5 & 97.1 & 94.7 & 94.7 & 93.6 & 93.6 & 2 \\
\hline 3 & 4.2 & 3.6 & & 96.5 & 95.3 & 97.7 & 97.1 & 96.5 & 98.8 & 99.4 & 95.3 & 97.7 & 92.4 & 91.2 & 91.2 & 3 \\
\hline 4 & 7.4 & 6.7 & 3.6 & & 93.0 & 95.3 & 94.7 & 94.2 & 96.5 & 97.1 & 92.4 & 94.7 & 89.5 & 88.3 & 88.3 & 4 \\
\hline 5 & 6.1 & 6.7 & 4.8 & 7.4 & & 95.9 & 97.7 & 97.1 & 95.3 & 95.9 & 92.4 & 94.7 & 89.5 & 88.3 & 88.3 & 5 \\
\hline 6 & 6.1 & 5.5 & 2.4 & 4.8 & 4.2 & & 97.7 & 97.1 & 97.7 & 98.2 & 93.6 & 95.9 & 91.2 & 90.1 & 90.1 & 6 \\
\hline 7 & 4.2 & 4.8 & 3.0 & 5.5 & 2.4 & 2.4 & & 99.4 & 97.1 & 97.7 & 94.2 & 96.5 & 91.2 & 90.1 & 90.1 & 7 \\
\hline 8 & 4.8 & 5.5 & 3.6 & 6.1 & 3.0 & 3.0 & 0.6 & & 96.5 & 97.1 & 93.6 & 95.9 & 90.6 & 89.5 & 89.5 & 8 \\
\hline 9 & 4.8 & 4.2 & 1.2 & 3.6 & 4.8 & 2.4 & 3.0 & 3.6 & & 99.4 & 94.7 & 97.1 & 91.8 & 90.6 & 90.6 & 9 \\
\hline 10 & 4.2 & 3.6 & 0.6 & 3.0 & 4.2 & 1.8 & 2.4 & 3.0 & 0.6 & & 95.3 & 97.7 & 92.4 & 91.2 & 91.2 & 10 \\
\hline 11 & 4.2 & 3.0 & 4.8 & 8.0 & 8.0 & 6.7 & 6.1 & 6.7 & 5.5 & 4.8 & & 93.6 & 93.6 & 93.0 & 93.0 & 11 \\
\hline 12 & 4.8 & 5.5 & 2.4 & 5.5 & 5.5 & 4.2 & 3.6 & 4.2 & 3.0 & 2.4 & 6.7 & & 90.6 & 89.5 & 89.5 & 12 \\
\hline 13 & 6.1 & 5.5 & 8.0 & 11.4 & 11.4 & 9.3 & 9.3 & 10.0 & 8.7 & 8.0 & 6.7 & 10.0 & & 98.8 & 98.8 & 13 \\
\hline 14 & 7.4 & 6.7 & 9.3 & 12.7 & 12.7 & 10.7 & 10.7 & 11.4 & 10.0 & 9.3 & 7.4 & 11.4 & 1.2 & & 100.0 & 14 \\
\hline 15 & 7.4 & 6.7 & 9.3 & 12.7 & 12.7 & 10.7 & 10.7 & 11.4 & 10.0 & 9.3 & 7.4 & 11.4 & 1.2 & 0.0 & & 15 \\
\hline & 1 & 2 & 3 & 4 & 5 & 6 & 7 & 8 & 9 & 10 & 11 & 12 & 13 & 14 & 15 & \\
\hline
\end{tabular}

SUDi5/2008 O/SUDi1/99 FMD-0-01 skr-is085 FMD-0-UAE-7/99 FMD-0-Iran:1/2010 FMD-0-PAKS44/2008 FMD-0-Lahore-vaccine-VP1 FMD-0-Israel-07-6387 FMD-0-TAW/2ig9 FMD-O/JPN/2000 OIETH/30/94 O/CAMI5/2006 FMD-EGYPT-0-1-2014 FMD-EGYPT-0-2-2014 FMD-EGYPT-0-3-2014 


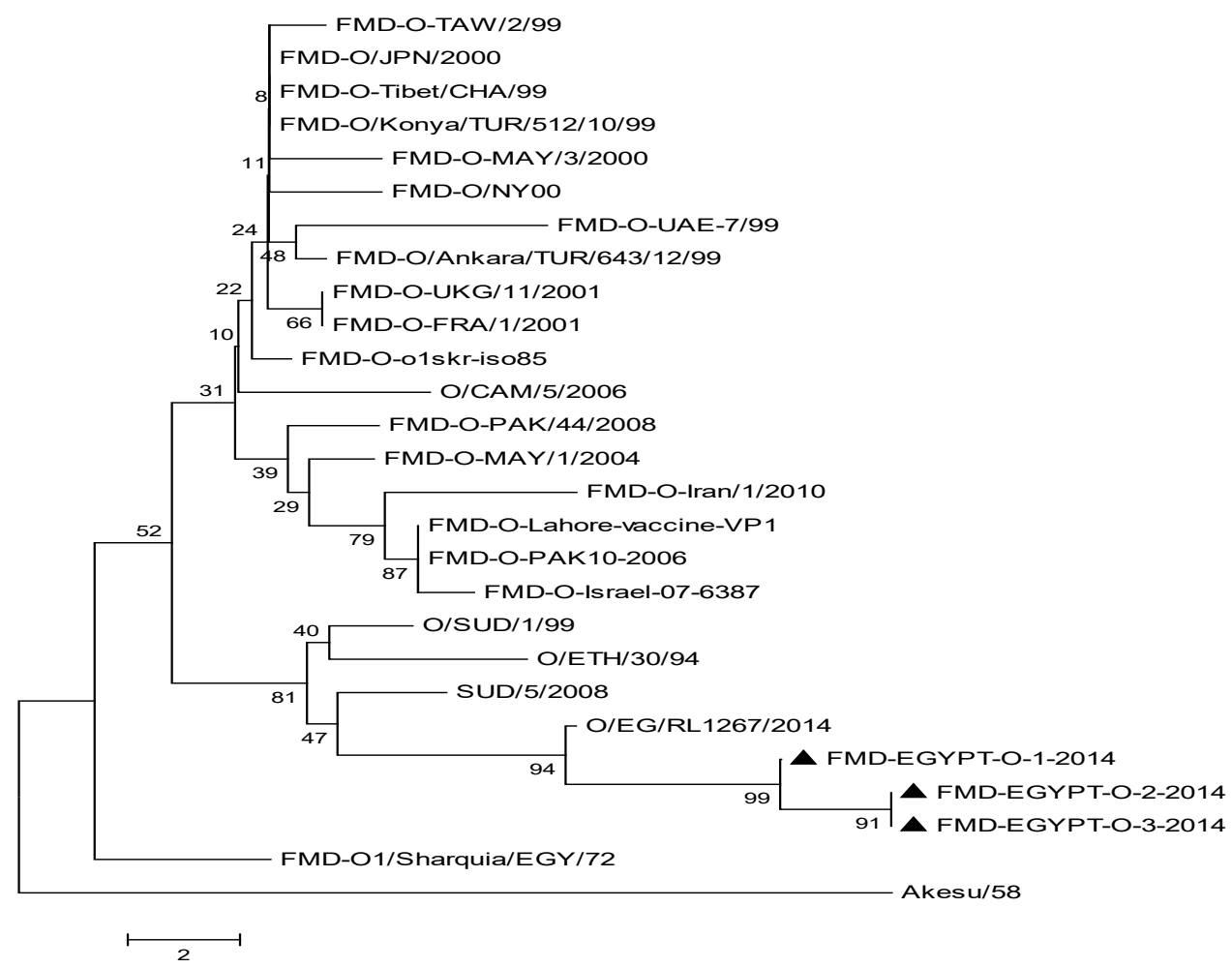

Fig.(2): Phylogenetic tree of VP1 of FMD virus serotype $O$ isolates. Black triangle represent kassasin, Ein-Ghosin, and Abu-sultan strains.

Discussion:

Foot-and-Mouth Disease considered fatal and contagious disease of cloven-footed animals (Coetzer et al., 1994). The disease caused by Seven distinct serotypes of FMDV. Infection of animal with one serotype can not protect this animal against subsequent infection with another serotype (Kitching et al., 1989 and Kitching, 1998). FMD make economic losses to international trade in livestock and animal products, the cause restricted to after acute stage of infection by FMDV may cause a prolonged, symptomless and carrier for virus for a long time (Alexandersen et al., 2002).

Data listed in Table (2) It was found that FMDV were positive in 30 viral isolates out of 41 samples by ELISA with a percentage of $73.2 \%$, however ELISA assay showed low sensitivity when used for direct diagnosis of FMDV in clinical samples with $70 \%$. These finding supported by (Roeder and Le Blanc Smith, 1987).

BHK-21 cells showed oblivious

CPE and high specificity for isolation of FMDV after 3 successive passage. The same 
results obtained by (Shawky et al., 2013). Data listed in Table (3) revealed that PCR assay are used for detection of FMDV in tongue epithelium, vesicular fluids and cell culture supernatants These findings agree with (Suryanarayana et al., 1999). Recently, an RT-PCR assay seems to be of sufficient sensitivity, specificity and robustness for diagnostic work, unless supported by the other techniques (Moss and Haas, 1999).

In this study RT-PCR assay were used for typing of FMDV and showed a predicted band specific for VP1 at 600bp Fig (1), RT-PCR assay has been used for the detection of FMDV in oral swab samples collected from apparently healthy animals (Klein et al., 2008), also from milk samples (Reid et al., 2006) and used for the detection of within- and between-pen transmission of FMDV in pigs (Eble et al., 2006).

Alignment and comparison of VP1 nucleotides of the three FMDV isolates serotype $\mathrm{O}$ (El-kassasin, Ein-Ghosin and Abu-Sultan strains) showed that the three sequences are closely related to each other with high identity percent ranged from 98.8-100\%. Ein-Ghosin virus strain are completely identical $(100 \%)$ to Abu-Sultan strain and quietly distinct from El-Kassasin virus strain with sequence divergence of $1.2 \%$. From the obtained sequence alignment results, we can conclude that Abu- Sultan and Ein-Ghosin strain are the same FMDV serotype $\mathrm{O}$ and can circulate between the two localities but differ from ElKassasin strain.

When the VP1 sequence of the current strains compared to other Egyptian and non Egyptian strains submitted to gene bank, it showed that great divergence ranged between 1.2 and $12.7 \%$, meanwhile, sequence comparison with O Sudan 52008 strain showed a great identity ranged between 93 to $94.2 \%$ indicating that the FMDV type $\mathrm{O}$ viruses circulating in Ismailia may evolved from the FMDV circulating in Sudan (O Sudan 5 2008) based on the criterion of at least $7.5 \%$ nucleotide difference in the VP1 coding region for a separate lineage and $15 \%$ for a genotype (Mohapatra et al., 2002 and Tosh et al., 2002).

FMDV type $\mathrm{O}$ strains isolated from Ismailia during 2013 and 2014 belongs to EA-3 topotype which differs phylogenetically from the vaccinal strain of the vaccine produced by Serum and Vaccine Research Institute, Abbassia(O/EGY/93 and $\mathrm{O}$ PanAsia-2) which belongs to MESA topotype so it is advisable to include these isolates of the new topotype or the most closely related reference strain $(\mathrm{O} / \mathrm{SUD} / 2008)$ in the vaccine production to induce complete protection against circulating viruses. 
Refrences:

Alexandersen, S.; Zhang, Z. and Donaldson, A. (2002): Aspects of the persistence of foot-and-mouth disease virus in animals-the carrier problem. Microbes and Infection, 4, 1099-1110.

Coetzer, J.A.W.; Thomsen, G.R.; Tustin, R.C. and Kriek, N.P.J. (1994): Foot-and-mouth disease. In: Infectious Diseases of Livestock with Special Reference to Southern Africa, J. A. W., Coetzer, G. R., Thomsen, R. C., Tustin and N. P. J., Kriek (Eds) Oxford University Press, Cape Town, 825-852.

Domingo, E., Baranowski, E., Escarmis, C. andSobrino, F. (2002):Foot-and-mouth iseasevirus.Comparative

Immunology, Microbiology and Infectious Diseases, 25, 297-308.

Eble, P.L.; de Bruin, M.G.; Bouma, A.; van Hemert-Kluitenberg, $F$. and Dekker, A. (2006): Comparison of immune responses after intra-typic heterologous and homologous vaccination againstfoot-and-mouth disease virus infection in pigs. Vaccine, 24; 1274-81.

El-Nakashly, S.A.; Abou Zaid, A.A.; Samira El-Kilany and Abd El-Aty, M.M. (1996): Isolation and identification of foot and Mouth Disease virus during an outbreak of 1993 in Egypt. $7^{\text {th }}$ Sci. Cong., Fac. Vet. Med., Assuit, Egypt, 679-688.

FAO (2012): FAO, 2012. FAOECTAD/EUFMD-workshop on FMD.http://www.fao .org/ag/ againfo/commissions/en/eufmd/euf md.html.
Farag, M. A.; Alsokayran, A.; Mazloum, K. S. and Al-Bokmy, A. M. (2005): The role of small ruminants in the epizootology of foot and mouth disease in Saudi Arabia with reference to the economic impact of the disease on sheep and goats. Veterinary Medical Journal 40, 23-41.

Giridharan, P.; Hemadri, D.; Tosh, C.; Sanyal, A. and Bandyopadhyay, S. K. (2005): Development and evaluation of a multiplex PCR for differentiation of foot-and-mouth disease virus strains native to India. $\mathrm{J}$ Virol Methods 126, 1-11.

Kitching, R. P.; Knowles, N. J.; Samuel, A. R. and Donaldson, A. I. (1989): Development of foot-andmouth disease virus strain characterization-a review. Tropical Animal Health and Production, 21, 153-166.

Kitching, R. P. (1998): A recent history of foot-and mouth disease. Journal of Comparative Pathology, 118, 89-108.

Klein, J.; Hussain, M.; Ahmad, M.; Afzal, M. and Alexandersen, S. (2008): Epidemiology of footand-mouth disease in Landhi Dairy Colony, Pakistan, the world largest Buffalo colony. Virol. J., 5, 53-68.

Knipe, T., Rieder, E., Baxt, B.,Ward, G., Mason,P.W. (1997): Characterization of synthetic FMD provirions separates acid-mediated disassembly from infectivity. J.Virol., 71: 2851-2856.

Knowles, N. J. and Samuel, A. R. (2003):Molecular epidemiology of 
foot-and-mouth disease virus. Virus Research, 91, 65-80.

Knowles, N.J, Davies, P.R, Midgley, R.J, Vaarcher,J.F. (2004):Identification of a ninth FMDV type $O$ topotype and evidence for a recombination event in its evolution. Report of the session of the research group of the standing technical committee of EUFMD, China, Crete, Greece, 2004 Oct. 12-15 Rome: Food and agriculture organization; Appendix 24.P.163-172.

Knowles, N.J. J. ;Wadsworth, S. M. ; Reid, K. G.; Swabey, A. A. ;El-Kholy, A. O. A.; El-Rahman, H. M. ;Soliman, K.; Ebert, N. P. ; Ferris, G. H. Hutchings, R. J.; Statham, D. P. ;King, D. J. and Paton (2007): Recent introduction of footand-mouth disease virus serotype A into Egypt. Emerg. Infect. Dis. 13, 1593-1596.

Lewis, S.A, Morgan, D.O., Grubman, M.J. (1991): Expression, processing and assembly of FMDV capsid structures in heterologous systems: introduction of a neutralizing antibody response in guinea pigs. J. Virol. 56: 6572: 6580.

Macpherson ,I. and Stocker, M.G.P.(1962):Polyoma transformation of hamster cell clones and investigation of genetic factors affecting cell competence.Virology16,147-151.

Mohapatra, J.K.; Sanyal, A.;Hemad ri, D.; Tosh, C.; Sabarinath, G.P. an d Venkataramanan, $R$. (2002): Sequence and phylogenetic analysis of the L and VP1 genes of foot-and-mouth disease virus serotype Asia1. Virus Res. 87,107118.

Moss, A. and Haas, B. (1999): Comparison of the plaque test and reverse transcription nested PCR for the detection of FMDV in nasal swabs and probing samples. Journal of Virological Methods, 80,59-67.

OIE (2004): Foot-and-mouth disease. In: Mannual of standardsfor Diagnostic Tests and Vaccines for Terrestrial Animals $5^{\mathrm{TH}} \mathrm{Edn}$. Paris, OIE.

OIE (2008): Foot and mouth disease. In: OlE Standards Commission (5th Eds.), Manual of Standards for Diagnostic Tests and Vaccines.Office International des Epizooties, Paris, France.

Reid, S.M.; Parida, S.and King, D.P.(2006): Utility of automated real-time RT-PCR for the detection of foot-and-mouth disease virus excreted in milk. Vet. Res., 37, 121132.

Roeder, P. L. and Le Blanc Smith, P. M. (1987): Detection and typing of foot-and-mouth disease virus by enzyme-linked immunosorbent assay: a sensitive, rapid and reliable technique for primary diagnosis. Research in Veterinary Science, 43,225 - 232.

Rueckert, R. R. (1995): Picornaviridae: the viruses andtheir replication in: Fields B.N., Knipe D.M., Howley P.M.,(E.d), Fields virology, 3rd ed., Lippincott-Raven, Philadelphia.

Saiz, M.; De La Morena, D. B.; Blanco, E.; Nunez, J. I.; Fernandez, R. and Sanchez- Vizcaino, J. M. 
(2003):Detection of foot-and-mouth disease virus from culture and clinical samples by reverse transcription-PCR coupled to restriction enzyme and sequence analysis. Vet Res 34, 105-117.

Samuel, A. R. and Knowles, N. J. (2001):Foot-and-mouth disease type $\mathrm{O}$ viruses exhibit genetically and geographically distinct evolutionary lineages (topotypes). Journal of General Virology 82, 609-621.

Shin, J.H.; Sohn, H.J.; Choi, K.S.; Kwon, B.J.; Choi, C.U.; Kim, J.H.; Hwang, E.K.; Park, J.H.; Kim, J.Y.; Choi, S.H. and Kim, O.K .(2003): Identification and isolation of footand-mouth disease virus from primary suspect cases in Korea in 2000.J Vet Med Sci 65:1-7

Shawky, M.; Abd El-Aty, M.; Fakry, H.M.; Daoud, H.M.; Ehab El-Sayed, I.;Wael Mossad, G.; Rizk, S.A.; AbuElnaga, H.; Mohamed, A. A.; Abd Elkreem, A. and Farouk, E. M. (2013):
Isolation and Molecular characterization of Foot and Mouth Disease SAT2 Virus during Outbreak 2012 in Egypt. J. Vet. Adv., 3(2), 60-68.

Suryanarayana, V.; Madanamohan, B.; Bist, P.; Natarajan,C. and Tratschin,J.D. (1999): Serotyping offoot-andmouth disease virus by antigen capturereverse transcriptase/ polymerase chain reaction. Journal of Virological Methods 80,45 - 52 .

Tosh, C.; Sanyal, A.; Hemadri, D. and Venkataramanan, R.(2002): Phylogenetic analysis of serotype A foot-and-mouth disease virus isolated in India between 1977 and 2000. Arch. Virol. 147, 493-513.

Zahran, G. E. (1960): Foot-andmouth disease virus. II. Propagation and modification of 3 immunologic types of virus in embryonating chicken eggs.Am J Vet Res 22, 527-532.

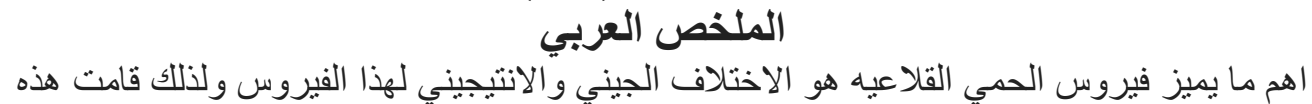

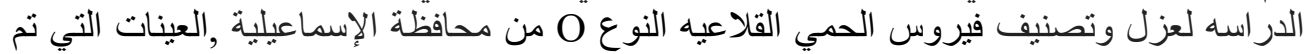

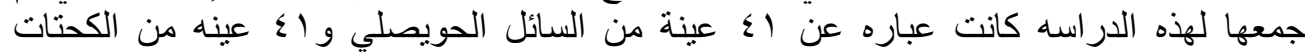

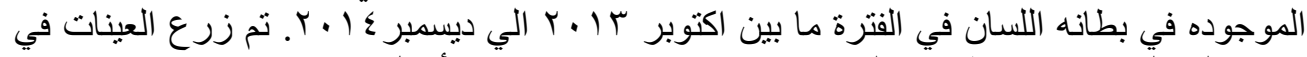

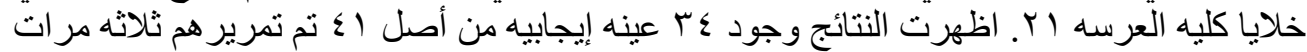

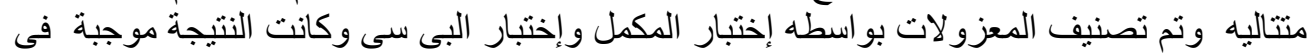

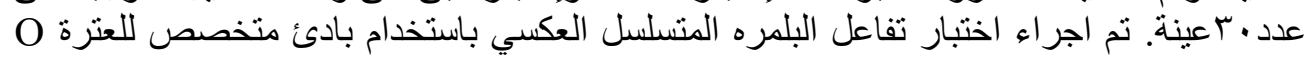

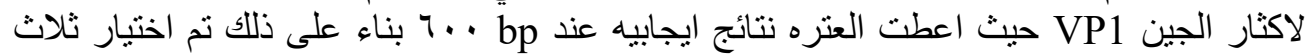

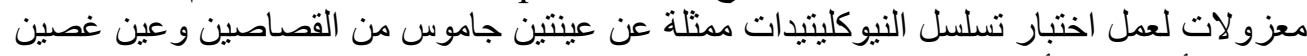

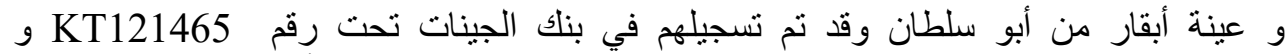

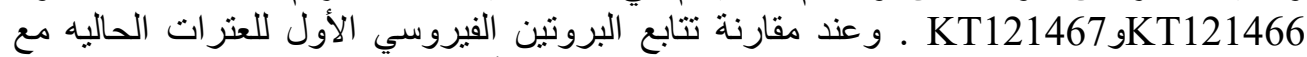

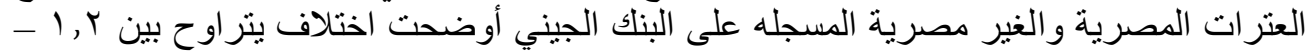

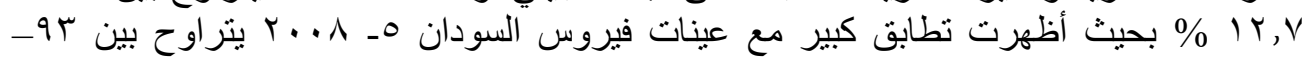

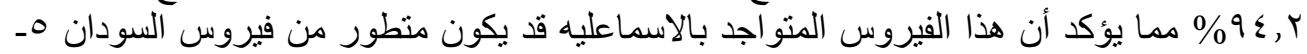

